\title{
Sources of Antibiotic Resistance Genes in a Rural River System
}

McConnell, Mandy M.; Hansen, Lisbeth Truelstrup; Neudorf, Kara D.; Hayward, Jenny; Jamieson, Rob C. ; Yost, Chris K.; Tong, Anthony

Published in:

Journal of Environmental Quality

Link to article, DOI:

10.2134/jeq2017.12.047

Publication date:

2018

Document Version

Peer reviewed version

Link back to DTU Orbit

Citation (APA):

McConnell, M. M., Hansen, L. T., Neudorf, K. D., Hayward, J., Jamieson, R. C., Yost, C. K., \& Tong, A. (2018). Sources of Antibiotic Resistance Genes in a Rural River System. Journal of Environmental Quality, 47(5), 9971005. https://doi.org/10.2134/jeq2017.12.047

\section{General rights}

Copyright and moral rights for the publications made accessible in the public portal are retained by the authors and/or other copyright owners and it is a condition of accessing publications that users recognise and abide by the legal requirements associated with these rights.

- Users may download and print one copy of any publication from the public portal for the purpose of private study or research.

- You may not further distribute the material or use it for any profit-making activity or commercial gain

- You may freely distribute the URL identifying the publication in the public portal 


\section{Sources of Antibiotic Resistance Genes in a Rural River System}

3 Mandy M. McConnell ${ }^{\mathrm{a}}$, Lisbeth Truelstrup Hansen ${ }^{\mathrm{b} * 1}$, Kara D. Neudorf ${ }^{\mathrm{b}}$, Jenny L. Hayward ${ }^{\mathrm{a}}$,

4 Rob C. Jamieson ${ }^{\mathrm{a}}$, Chris K. Yost ${ }^{\mathrm{c}}$, Anthony Tong ${ }^{\mathrm{d}}$.

5 a Department of Civil and Resources Engineering, Dalhousie University, 1360 Barrington Street, 6 Halifax B3H 4R2, Canada

$7 \quad{ }^{\mathrm{b}}$ Department of Process Engineering and Applied Science, Dalhousie University, 1360

8 Barrington Street, Halifax B3H 4R2, Canada

$9{ }^{\mathrm{c}}$ Department of Biology, University of Regina, 3737 Wascana Parkway, Regina, SK S4S 0A2, 10 Canada

$11{ }^{\mathrm{d}}$ Department of Chemistry, Acadia University, 6 University Avenue, Wolfville, Nova Scotia

12 Canada B4P 2R6

*Corresponding author at: Technical University of Denmark, Denmark.

15 E-mail address: litr@food.dtu.dk (L. Truelstrup Hansen).

$16{ }^{1}$ Present address: National Food Institute, Technical University of Denmark, DK-2800 Kongens

17 Lyngby, Denmark.

\section{List of Abbreviations Used}

$\mathrm{AB}$

Antibiotic

AL

Aerated Lagoon

23 AR

Antibiotic Resistance

24 ARB

Antibiotic Resistant Bacteria

ARG Antibiotic Resistance Gene

$26 \mathrm{CBOD}_{5}$

27 E. coli

28 gDNA

Five-Day Carbonaceous Biochemical Oxygen Demand

Escherichia coli

Genomic DNA

29 HGT

Horizontal Gene Transfer

LOD Limit of Detection

LOQ

Limit of Quantification

MGE

qPCR

Mobile Genetic Element

33

TSS

Quantitative Polymerase Chain Reaction

35 WWTP

Total Suspended Solids

Wastewater Treatment Plant 


\section{Core Ideas}

41 -Tertiary wastewater treatment contributed antibiotic resistance genes (ARG) to the river

42 -ARG levels decreased as proximity to anthropogenic influence decreased

43 -ARGs were observed at detectable levels even in undeveloped headwaters

44 -High flow conditions correlated to high ARG loading in the river

45 -Positive correlations were found between ARGs and fecal indicators

46 Abstract

47 The increasing prevalence of antibiotic resistance genes (ARGs) in the environment is

48 problematic due to the risk of horizontal gene transfer and development of antibiotic resistant

49 pathogenic bacteria. Using a suite of monitoring tools this study aimed to investigate the sources

50 of ARGs in a rural river system in Nova Scotia, Canada. The monitoring program specifically

51 focused on the relative contribution of ARGs from a single tertiary level wastewater treatment

52 plant (WWTP) in comparison to contributions from the up-gradient rural, sparsely developed,

53 watershed. The overall gene concentration significantly $(\mathrm{p}<0.05)$ increased downstream from the

54 WWTP, which suggested that tertiary level treatment still contributes ARGs to the environment.

55 As a general trend, ARG concentrations upstream were found to decrease as proximity to

56 human-impacted areas decreased; however, many ARGs remained above detection limits in

57 headwater river samples, which suggested their ubiquitous presence in this watershed in the

58 absence of obvious pollution sources. Significant correlations with ARGs were found for $H F 183$

59 human fecal marker, Escherichia coli, and some antibiotics, which suggested that these markers

60 may be useful for prediction and understanding of ARG levels and sources in rural rivers. 


\section{Introduction}

63 Effluents from wastewater treatment plants (WWTPs) have recently been shown to

64 contribute to increased levels of antibiotic resistance (AR) in receiving environments by

65 increasing levels of antibiotic resistant bacteria (ARB), antibiotic resistance genes (ARGs), and

66 AR selective factors, such as antibiotics (ABs) (Berglund et al., 2015; Makowska et al., 2016;

67 Proia et al., 2016; Rodriguez-Mozaz et al., 2015). Although WWTPs have been shown to

68 decrease levels of ARGs throughout treatment, even tertiary effluents have been shown to

69 contain considerable levels of ARGs, which are subsequently discharged into the environment

70 (Rodriguez-Mozaz et al., 2015). Antibiotic resistance genes may persist even after selective

71 pressures, such as ABs are removed making them extremely difficult to eliminate (Salyers and

72 Amábile-Cuevas, 1997). Antibiotic resistance genes are often present on mobile genetic

73 elements (MGEs) such as plasmids, transposons, and integrons, which allows for their horizontal

74 gene transfer (HGT) between bacteria (Davies and Davies, 2010). Therefore, it is important to

75 limit sources which pollute the environment with AR determinants, as once present, they can

76 persist and spread, which leads to increased risk of creation of AR human pathogens.

77 Past studies have examined the effects of WWTP discharges on ARG presence in

78 receiving waters in urban/anthropogenically impacted areas (Berlung et al., 2015). Proximity to,

79 and increased levels of urbanization is often associated with higher levels of AR in the

80 environment (Ouyang et al., 2015). However, the levels in relatively undeveloped watersheds

81 have not been well documented. Quantification of ARG concentrations and loads in rural and

82 remote areas, which are less influenced by anthropogenic activities, would help characterize the

83 role that an individual WWTP has on contribution of ARGs to the environment, and provide

84 insight into ARG levels that already exist in the environment in rural regions. Knapp et al. (2012) 
85 also showed that seasonal changes in streamflow can influence the distribution and levels of

86 ARGs in receiving water environments, which highlighted the demand for ARG monitoring

87 programs to adequately capture hydrologic variability.

88 In recognition of these research gaps, the objective of this study was to characterize the

89 relative role of an individual tertiary WWTP on ARG presence within a rural watershed under

90 variable hydrologic conditions. A monitoring program was designed to measure both the

91 concentration (copies $/ \mathrm{mL}$ ) and load (copies/second) of a suite of ARGs throughout the catchment

92 upstream of the WWTP discharge to quantify background levels of ARGs in a relatively

93 undeveloped, rural watershed. Sampling occurred during wet and dry events to assess how

94 hydrology influences ARG abundances and loading. A suite of additional water quality

95 indicators (generic Escherichia coli and human specific Bacteroidales markers) were also

96 assessed to identify potential indicators of ARG presence, and help confirm potential sources.

99 2.1 Sampling sites and sample collection

100 Wastewater samples were collected from a municipal tertiary WWTP located in Greenwood, 101 Nova Scotia, Canada ( $44^{\circ} 57^{\prime} 42^{\prime \prime}$ N, $64^{\circ} 55^{\prime} 44^{\prime \prime}$ W) that services a population of 6500 people

102 (Statistics Canada, 2011). The WWTP discharges approximately 1 MGD $\left(3.8 \times 10^{6} \mathrm{~L} /\right.$ day $)$ into

103 the Fales River, which is tributary to the Annapolis River. There are between 600-800 customer 104 connections, which includes a Canadian Forces airbase which contains a small hospital unit.

105 Treatment units include primary clarifiers, two aerated lagoons (ALs), two secondary clarifiers, 106 sand filtration, and UV disinfection. The plant must adhere to a strict regulatory effluent 107 discharge requirement of a maximum content of $5 \mathrm{mg} / \mathrm{L}$ for five-day carbonaceous biochemical 

oxygen demand $\left(\mathrm{CBOD}_{5}\right)$ and $5 \mathrm{mg} / \mathrm{L}$ for total suspended solids (TSS). Sample collection that included influent (I) [after primary clarifiers], effluent (E) [after

110 UV disinfection], downstream (D), and upstream 1 (UP1) water samples was performed on 111 August 18/2015 (summer/dry weather event), February 23/2016 (winter/dry weather event), 112 April 12/2016 (early spring/wet weather event), May 10/2016 (late spring/dry weather event), 113 and August 2/2016 (summer/dry weather event). Samples labeled as a dry weather event were 114 collected during baseflow periods, while samples were labeled as a wet weather event if samples 115 were collected during a storm hydrograph event. For the sampling dates April 12/2016, May 116 10/2016, and August 2/2016, an additional six upstream water sites were sampled (UP2 to UP7).

117 Figure 1 and Table 1 illustrate the locations of these collection sites and provide characteristics 118 of their drainage areas. Upstream sample collection sites were chosen to represent points along 119 both primary tributaries in closer proximity of (UP2, UP3, UP4, UP6), and further away (UP5, 120 UP7) from urbanization and human-impacted areas. The watershed delineation, stream network, 121 and land use mapping was created using ESRI ArcGIS ArcMap 10@ software. A hydrologically 122 correct $20 \mathrm{~m}$ Digitial Elevation Model was sourced from Government of Nova Scotia (2006), 123 and the Canvec geospatial dataset (Government of Canada (2016a,b) was used to conduct the 124 land-use characterization.

125 Samples were collected in pre-sterilized 1 L Nalgene collection bottles (Thermo Fisher 126 Scientific). Water samples were kept on ice while being transported back to the laboratory at 127 Dalhousie University in Halifax, NS and stored in the fridge at $4^{\circ} \mathrm{C}$ until analysis. All samples 128 were processed within their respective sample holding times. 
1302.2 Analysis of the Abundance of Antibiotic Resistance Genes, Human Fecal Markers and 16S

131 rRNA Gene Copies

$132 \quad 2.2 .1$ Genomic extraction

133 Microorganisms in wastewater and river samples were concentrated (in quantities ranging

134 from 50 (influent) to $500 \mathrm{~mL}$ (effluent and river samples)) by filtration through $0.45 \mu \mathrm{M}$

135 membranes using a vacuum manifold (Millipore, Inc., Bedford, MA). Filters were stored at -

$13620^{\circ} \mathrm{C}$ until DNA extraction. Genomic DNA was extracted from the entire filter using the MoBio

137 Powersoil DNA extraction kit (VWR International, Ville Mont-Royal, QC, Canada) according to

138 manufacturer's specifications and stored at $-20^{\circ} \mathrm{C}$. The concentration and purity of the DNA

139 were evaluated by ultraviolet absorbance spectrophotometry at 260/280 nm and 260/230 nm

140 (Implen NanoPhotometer ${ }^{\mathrm{TM}}$, Implen, München, Germany).

142 2.2.2 Quantitative real-time PCR

143 Assessment of gene targets was performed using quantitative real-time PCR (qPCR).

144 Primer and probe sequences and cycling conditions for nine antibiotic resistance genes and one

145 integrase gene (int l) used as a proxy to assess ARG cassettes and mobility potential (Norman et

146 al., 2009; Toleman et al., 2006), were obtained from the literature and are detailed in Supporting

147 Material (Table S1). The genetic targets assessed in this study include class 1 integrase (int1),

148 class A $\beta$-lactamase ( $b l a_{C T X-M}$ and $\left.b l a_{T E M}\right)$, erythromycin resistance gene $($ erm $B)$, fluoroquinolone

149 resistance gene ( $q n r S)$, sulphonamide resistance genes ( $s u l 1$ and sul2), tetracycline resistance

150 gene (tet $O)$, methicillin resistance gene ( $m e c A)$, and vancomycin resistance gene (vanA). These

151 ARGs were chosen to represent a variety of different AB classes and resistance mechanisms as

152 well as clinically relevant genes (Szczepanowski et al., 2009; Volkmann et al., 2004). Human- 
153 specific HF183 Bacteroidales 16S rRNA genetic marker was also quantified to examine a

154 potential correlation between human faecal pollution and ARG abundance (Sauer et al., 2011).

155 The concentration of bacterial 16S rRNA was also determined by qPCR to allow for the

156 calculation of the relative abundance of ARG relative to the 16S rRNA copy numbers (Neudorf

157 et al., 2017). All targets were quantified in all water samples and were run in duplicates for

158 samples, and triplicates for positive control standards and no template controls (NTCs). Control

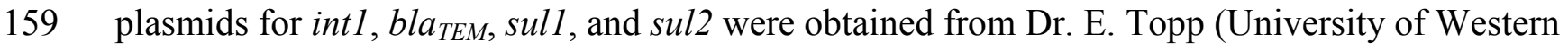

160 Ontario, London, ON, Canada) and described in Rahube et al. (2014). Control plasmids for

161 bla CTX-M $_{\text {ermB }}$, qnrS, tetO, mecA, and vanA are described in Neudorf et al. (2017).

162 Concentrations of plasmid DNA were quantified using Quant-iT PicoGreen dsDNA Assay Kit

163 (Thermo Fisher Scientific). Standard curves were constructed for each assay using tenfold serial

164 dilutions of positive controls in triplicate. Quality assurance for standard curves were performed

165 according to recommendations from the Bio-Rad Real-Time PCR Applications Guide (Bio-Rad,

166 2013). Efficiencies ranged from $87.3 \%$ to $114.5 \%$ and $R^{2}$ values were $>0.99$ for all calibration

167 curves. Limit of quantification (LOQ) (copies/reaction) were as follows: int $1=14.4$, sull $=11.7$,

168 sul2=9.6, $\operatorname{tet} O=69.0, \operatorname{erm} B=13.8, b l a_{C T X-M}=6.2, b l a_{T E M}=243.0, q n r S=112.0$, mecA $A=69.0$,

$169 v a n A=138.0,16 \mathrm{~S}$ rRNA $=67000, H F 183=3630$, which are similar to values reported in the

170 original papers. Limit of detection (LOD) was 5 copies/reaction (or 1 copy $/ \mathrm{mL}$ for $500 \mathrm{~mL}$

171 sample volumes and 10 copies $/ \mathrm{mL}$ for $50 \mathrm{~mL}$ sample volumes).

172 TaqMan qPCR on a Bio-Rad CFX96 Touch system (Bio-Rad, Hercules, CA, USA) was

173 used in quantification of int 1 and ARGs. The following reaction mixture was used: $1 \mathrm{x}$

174 SsoAdvanced ${ }^{\mathrm{TM}}$ Universal Probes Supermix (Bio-Rad), $0.9 \mu \mathrm{M}$ of each primer, $0.25 \mu \mathrm{M}$

175 TaqMan probe, $2 \mu \mathrm{l}$ template DNA, and $2 \mu \mathrm{l}$ of sterile nuclease-free water (Thermo Fisher) to a 
176 final volume of $20 \mu \mathrm{l}$. Water samples and negative controls without template DNA reactions

177 were run in duplicate, while standards (control plasmid) reactions were run in triplicate. Taqman

178 probes were also used in quantification of the human faecal HF183 marker. The following

179 reaction mixture was used: $1 \mathrm{x}$ SsoAdvanced ${ }^{\mathrm{TM}}$ Universal Probes Supermix (Bio-Rad), $0.6 \mu \mathrm{M}$ of

180 each primer, $0.25 \mu \mathrm{M}$ TaqMan probe, $2 \mu \mathrm{l}$ template DNA, and $6.5 \mu \mathrm{l}$ of sterile nuclease-free

181 water (Thermo Fisher Scientific) to a final volume of $25 \mu$ l. SYBR Green qPCR was used to

182 quantify universal 16S rRNA gene fragments. The following reaction mixture was used: $10 \mu 1$

183 Power SYBR ${ }^{\circledR}$ Green PCR Master Mix (Applied Biosystems, Foster City, CA, United States),

$184 \quad 0.4 \mu \mathrm{M}$ primers, and $1 \mu \mathrm{l}$ of template DNA, and $7.4 \mu \mathrm{l}$ of sterile nuclease-free water (Thermo

185 Fisher Scientific) to a final volume of $20 \mu \mathrm{l}$. All SYBR Green qPCRs were run in triplicate

186 including negative controls without template DNA.

$188 \quad 2.3$ Assessment of Water Quality

189 All samples were tested for the following water quality parameters: total suspended solids

190 (TSS), volatile suspended solids (VSS), ammonia, nitrate, and Escherichia coli. Wastewater

191 samples were also tested for $\mathrm{CBOD}_{5}$, total nitrogen (TN), total phosphorous (TP), and chemical

192 oxygen demand (COD). TSS and VSS were performed using Whatman ${ }^{\mathrm{TM}}$ 934-AH 47 mm glass

193 fiber filters (Thermo Fisher Scientific) according to APHA standard methods 2540 D (American

194 Public Health Association, 1999). Ammonia and nitrate were measured using high performance

195 ammonia and nitrate electrodes, respectively, as directed by the manufacturer (Thermo Fisher

196 Scientific). The electrodes were attached to an Orion Star ${ }^{\mathrm{TM}}$ series meter (Thermo Fisher

197 Scientific). E. coli was measured using IDEXX Colilert ${ }^{\circledR}-18$ and Quanti-Trays ${ }^{\circledR}($ IDEXX

198 Laboratories, Inc., Westbrook, ME, United States) according to the manufacturer's instructions 
199 in IDEXX Laboratories, Inc. (2012). Analysis of $\mathrm{CBOD}_{5}$ was performed in duplicate according 200 to the APHA standard method 5210B (American Public Health Association, 1999). TN was 201 analyzed using $\operatorname{Hach}^{\circledR} \mathrm{TN}$ Test 'N Tubes ${ }^{\mathrm{TM}}$ (0.5 to $25.0 \mathrm{mg} / \mathrm{L}$ N, Hach Company, Loveland, CO, 202 United States), according to the manufacturer's procedure. TP was analyzed using Hach ${ }^{\circledR}$ TP 203 Test ' $\mathrm{N}$ Tube ${ }^{\mathrm{TM}}$ ranging from 1.0 to $100.0 \mathrm{mg} / \mathrm{L} \mathrm{PO}^{3-}$ (Hach Company), following the 204 manufacturer's procedure. COD was analyzed using Hach ${ }^{\circledR}$ COD TNT plus Vial ${ }^{\mathrm{TM}}$ Test ranging 205 from $20-1500 \mathrm{mg} / \mathrm{L}$ COD (Hach Company), following the manufacturer's procedure.

206 Water quality measurements for temperature $\left({ }^{\circ} \mathrm{C}\right)$, conductivity $(\mu \mathrm{S} / \mathrm{cm})$, dissolved 207 oxygen (DO (both \% and $\mathrm{mg} / \mathrm{L})$ ), $\mathrm{pH}$, and oxidation reduction potential (ORP $(\mathrm{mV})$ ), were 208 conducted on samples in-situ using a handheld YSI 600R or 600QS multi-parameter water 209 quality sonde (YSI Inc., Yellow Springs, OH United States). River flow rates were determined 210 using the velocity - area method (Dingman, 2002). Velocity and depth were measured using a

211 Gurley Precision Instruments (Troy, NY, United States) 625DF2N digital pygmy meter.

213 2.4 Antibiotics Analysis

214 The samples were also tested for a range of 10 clinically relevant antibiotics consisting of 215 amoxicillin, cefaclor, cefprozil, cefdinir, levofloxacin, ciprofloxacin, azithromycin, clindamycin, 216 clarithomycin, and triclocarban. A vacuum filter apparatus equipped with $3 \mathrm{~mL}$ Chromabond ${ }^{\circledR}$ 217 HR-X (200 mg sorbent) solid phase extraction (SPE) columns was used to extract the target 218 antibiotics. These SPE columns were conditioned with $6 \mathrm{~mL}$ methanol and $6 \mathrm{ml}$ of deionized 219 (DI) water. The $\mathrm{pH}$ was measured from $100 \mathrm{~mL}$ samples and adjusted to $\mathrm{pH} 2.5 \pm 0.5$ with $1 \mathrm{M}$ $220 \mathrm{HCl}$. The samples were then pumped through the column at $5 \mathrm{~mL} / \mathrm{min}$ under vacuum. Cartridges 221 were washed with $3 \mathrm{~mL}$ of $10 \%(\mathrm{v} / \mathrm{v})$ methanol in DI and dried for 5 min under vacuum. 
222 Analytes were eluted using $3 \mathrm{~mL}$ of methanol two times for a total of $6 \mathrm{~mL}$. Eluent was collected

223 and reduced to $1 \mathrm{~mL}$ with gentle nitrogen blowdown at approximately $37{ }^{\circ} \mathrm{C}$. Antibiotic analysis

224 was performed using an Agilent 1200 HPLC coupled with an Agilent 6410 triple quadrupole

225 mass spectrometer. Chromatographic separation was performed using a 25-cm Agilent Poroshell

226 Eclipse C18 column with a 4.6-mm internal diameter and 2.7- $\mu \mathrm{m}$ particles. The flow rate of

227 mobile phase (a mix of methanol and ultrapure water) was $0.5 \mathrm{~mL} / \mathrm{min}$. A solvent gradient was

228 programed to start at $20 \%(\mathrm{v} / \mathrm{v})$ methanol for $0.5 \mathrm{~min}$, which increased to $100 \%$ by $20 \mathrm{~min}$, and

229 then held for another 5 mins with a maximum flow gradient of $100 \mathrm{~mL} / \mathrm{min}^{2}$. The column was

230 kept at a constant temperature of $40^{\circ} \mathrm{C}$. Following separation, ionization was conducted with an

231 electrospray ionization (ESI) source under 35-psi nebulizer pressure. Drying gas temperature was

232 set to $350^{\circ} \mathrm{C}$ with a flow rate of $12 \mathrm{~L} / \mathrm{min}$. The MS was operated in the positive mode and the

233 capillary voltage was held at $4000 \mathrm{~V}$. Nebulizing collision gases were $98 \%$ nitrogen and ultra-

234 high purity (UHP, 99.999 \%) nitrogen., respectively. Precursor-to-product ion transitions were

235 established for all target antibiotics. Quality assurance and quality control included the use of

236 continuing calibration verification, solvent blanks, spiked samples, internal standards, and

237 duplicate samples (technical replicates, $\mathrm{n}=2$ ).

2392.5 Data Analysis

240 Raw fluorescence data from the Bio-Rad qPCR system were processed using the

241 LinRegPCR program (v 11.4) (Ruijter et al., 2009). In order to account for differences in

242 efficiencies between samples and standards, a one-point calibration (OPC) method for absolute

243 quantification was used (Brankatschk et al., 2012). For statistical calculations, any values that

244 fell between the LOD and LOQ were set to $1 / 2$ of LOQ value. Any values that fell below the LOD 
245 were set to $1 / 2$ of the LOD. For calculation of the relative abundance of genes, the gene copy

246 (GC) number of each gene was normalized to the GC number of the 16S rRNA gene in each

247 sample and $\log$ transformed $(\log (\mathrm{GC} / 16 \mathrm{~S}$ rRNA GC) $)$. For calculation of the absolute abundance

248 of genes, gene copies were normalized to the water volume used for gDNA extractions to

249 generate GC per $\mathrm{mL}$ of water.

250 One-way analysis of variance (ANOVA), Tukey HSD test, and t-tests were used to assess

251 statistically significant differences $(\mathrm{p}<0.05)$ among samples. Pearson correlation coefficients

252 were used to assess significant $(\mathrm{p}<0.05)$ correlations between ARGs and water quality

253 parameters. Analysis was performed using GraphPad Prism version 7.00 for Mac OS X

254 (GraphPad Software, La Jolla California USA, www.graphpad.com), and Microsoft Excel, 2016.

255 Abundances for each individual ARG were pooled and averaged for each sampling site for the 256 statistical analyses.

\section{Results and Discussion}

2593.1 Presence and abundance of ARGs in WWTP influent and effluent samples

261 sampling events (August 18, 2015, February 23, 2016 April 12, 2016, May 10, 2016, and August

262 2, 2016). Exceptions included mecA, which was below the LOD on August 18, 2015 (all

263 samples) and on August 2, 2016 (effluent), and vanA, which was below the LOD in all samples

264 and will not be included in further analysis. There was a decrease of $1.93 \log$ units from the

265 influent to the effluent that was quantified with the pooled ARG absolute averages from the five

266 sampling events. This indicated that the WWTP decreased overall ARG absolute abundance

267 significantly $(\mathrm{p}<0.05)$ throughout treatment. The effluent leaving the WWTP consistently met 
268 the regulatory target values for both TSS and $\mathrm{CBOD}_{5}$ (both $5 \mathrm{mg} / \mathrm{L}$ ) during the sampling period, 269 which indicated that the plant operated efficiently (Table S2). A decrease of ARGs throughout 270 the treatment continuum is consistent with previous studies (Chen and Zhang, 2013; Gao et al.,

271 2015; Laht et al., 2014; Munir et al., 2011). However, the effluent still contained an average of

272 close to $3 \log$ units of ARGs/mL even after tertiary level treatment (see Figure 2a). Therefore,

273 although the effluent was reduced in ARG concentrations compared to influent, ARGs were still 274 present at detectable concentrations.

275

2763.2 Abundance and load of ARGs in water samples collected upstream (UP1) and downstream

277 (D) of the WWTP effluent discharge point

Analyses of downstream (D) and upstream 1 (UP1) samples from August 2015, and

279 February, April, May, and August 2016 sampling events revealed generally higher abundances

280 of ARGs downstream from the WWTP than upstream (Figure 2a). All ARGs were detected in

281 both UP1 and D samples, except for $b l a_{T E M}\left(<\right.$ LOD in UP1 and D samples in May), bla $a_{C T X-M}$

$282(<$ LOD in UP1 and D samples in April, as well as UP1 sample in May), sul2 ( $<$ LOD in D sample

283 in April), mecA (<LOD in both UP1 and D samples in August 2015 and August 2016 UP1

284 sample).

Although D samples often harboured a higher abundance of genes than UP1 samples,

286 comparisons (t-test) of UP1 and D samples averaged from all sampling events for each ARG,

287 showed only ermB was significantly $(\mathrm{p}<0.05)$ different, for both absolute $($ copies $/ \mathrm{mL})$ and

288 relative abundance (copies/16S rRNA gene copies). These results may suggest ermB to be more

289 tightly linked to anthropogenic impacted ecosystems, a finding which agrees with what was

290 recently reported for river recipient in Saskatchewan, Canada (Freeman et al., 2017). Significant 
291 differences $(p<0.05)$ were observed in absolute and relative abundances in the pooling the genes

292 (8 ARGs and int 1) for the UP1 and D samples. These results indicated that the WWTP

293 contributed to increased overall ARG concentrations and to an increased proportion of bacteria

294 which carried ARGs in water downstream from the plant.

295 The impact of the WWTP on the ARG concentrations in the river was higher during the

296 August sampling event, as there were larger differences between upstream and downstream

297 samples for most ARGs as well as higher concentrations than other months (Figure 2a).

298 However, ARG loading (log copies/sec) measurements suggest that less total ARGs were

299 transported in August (Figure 2b). River flow rates measured at the effluent discharge location

300 varied from $0.06 \mathrm{~m}^{3} / \mathrm{s}$ in August 2016 to $3.37 \mathrm{~m}^{3} / \mathrm{s}$ in April 2016. Higher downstream

301 concentrations in dry periods were caused by lower river levels and flows which caused the

302 effluent discharge to contribute more to the water levels downstream; as well as there being

303 lower upstream levels of ARGs during these sampling events. A study by Knapp et al. (2012)

304 which examined a river in Cuba during both wet and dry seasons also found that waste outfalls

305 more strongly influenced ARG levels in local downstream river samples in a drier season.

3073.3 Concentration and loading of ARGs in the upstream watershed

308 The concentration and load of the ARGs in the upstream river samples displayed

309 seasonal/weather event differences. For instance, April samples contained significantly $(p<0.05)$

310 higher ARG concentrations (log copies $/ \mathrm{mL}$ ) and load (copies/second) compared to May (second

311 most) and August (least) water samples (Figure 2). The highest stream flow was in April and

312 coincided with peaks in ARG levels, which suggested that hydrologic processes (surface runoff,

313 sediment resuspension) were likely involved in mobilization of ARGs. Knapp et al. (2012) also 
314 found seasonal variations in ARG levels in a river in Cuba, finding an increased overall

315 abundance of ARGs in the river in wet seasons when compared to dry seasons.

316 Higher concentrations and loads of ARGs in the upstream river were observed at most

317 sites in April with obvious "hotspots" observed in UP2, UP4, and UP6. Sites UP2, UP4, and UP6

318 contain some residential areas and a small of amount of agriculture in their drainage areas, which

319 may have contributed to these seasonal peaks in ARG abundance, as these factors have been

320 suggested to increase ARG levels (Ouyang et al., 2015).

321 Excluding the wet weather event in April 2016, gene concentrations followed a general

322 trend of lower concentrations the further upstream and away from urbanization/agriculture the

323 samples were taken. However, concentrations seemed to remain at a consistent level even at the

324 UP7 site, which does not possess any known pollution sources within its drainage area. This

325 suggests ARGs are present and can persist in the environment without known selective pressures,

326 which has been shown in previous studies (Nesme et al., 2014). The load of ARGs at UP7 was

327 actually higher in May and August than at the UP6 sampling site, which is more influenced by

328 anthropogenic activities. ARGs being transported through the river at a relatively unimpacted

329 sites suggests there may be unknown pollution source points, and also reconfirms that resistance

330 can be measured everywhere (Nesme et al., 2014). Although there are no known residences or

331 agricultural activities upstream of UP7, this area is used by local populations for hunting, fishing,

332 and camping and by the military, which may be contributing to the presence of ARGs at this

333 sampling location. Previous studies also reported higher ARG levels in more urban effected areas

334 when compared to more undeveloped environments (upstream); however low ARG levels were

335 still observed in samples from undeveloped areas (Ouyang et al., 2015; Pruden et al., 2006;

336 Stortebloom et al., 2010). 
Findings from this study and previous studies suggest that anthropogenic activities do

338 increase the levels of ARGs in the environment; however, ARGs also exist in watersheds with no

339 obvious human inputs. Even sub-lethal concentrations of ABs can sustain or exert a selective

340 force for AR in the environment, and once ARGs are established they can be replicated and

341 spread among bacteria (Martinez, 2009). It has been suggested that ABs have been produced

342 naturally for over 500 million years (Baltz, 2008). Antibiotics and ARGs have therefore existed

343 in the environment before human AB therapeutic uses came into effect (D'Costa et al., 2011).

344 Despite this natural presence, human activities (e.g., medical and agricultural uses of ABs) have

345 most likely increased the prevalence and spread of AR (Allen et al., 2010). Antibiotic resistance

346 has been shown to be able to spread throughout the environment through mechanisms such as

347 urban and agricultural runoff, wind, as well as biological forces such as animals and humans

348 (Allen et al., 2010). It is also possible that genes that confer resistance to antibiotics in pathogens

349 may have an alternative purpose in their original host, which may explain their presence in

350 different compartments of the environment without typical selective pressures (Martinez, 2009).

351 The variations in individual ARG levels among the sampling sites in the watershed are

352 shown for the ARGs in Figure 3. Most ARGs decreased as the samples were collected further

353 away from urbanization. However, the detection of $m e c A$ was unexpected including its highest

354 level of $3 \log (\mathrm{GC} / \mathrm{mL})$ in April and presence in some May upstream samples leading to the

355 sequencing of amplicons from some samples to positively confirm gene identity. Mec $A$ confers

356 resistance to antibiotics used as a last resort in clinical practices; therefore presence of this

357 resistance gene was expected to be low in the environment due to lower clinical use. MecA is

358 also often present on chromosomal DNA and therefore only carried by certain bacteria (e.g.

359 Staphylococcus aureus), which may limit its environmental presence (Katayama et al., 2000). It 
360 is possible that during these higher flow conditions $m e c A$ entered the river through releases from

361 melting snow, septic system discharges, storm runoff, presence of selective factors, and re-

362 entrainment from sediment during the increased flow. Int1, sul2, ermB, sul1, bla $a_{C T X-M}$ and mecA

363 were the genes that seemed to be most affected by the wet weather sampling event in April.

364 Likewise, $S u l 2$, ermB, sul1, $b l a_{C T X-M}$, and mecA were also not consistently present in upstream

365 samples, which indicated that the genes which flushed into the river in high abundances in April

366 seemed to be less commonly found in the river during other seasons. Int1 and tetO remained

367 present in consistently higher levels in water samples from both the river and WWTP compared

368 to other ARGs. TetO confers resistance to tetracycline ABs, an older group of highly consumed

369 ABs (Laht et al., 2014), which may explain its elevated presence.

371 3.4. Correlations between ARG abundance and fecal indicators

372 Figure 4 shows the concentrations of fecal indicator markers (E. coli, and HF183 human

373 Bacteroidales marker) in water samples obtained on the April, May and August sampling trips in

374 2016. Levels of $E$. coli decreased as a result of wastewater treatment and remained close to the

375 detection limit in the more remote portions of the watershed (e.g., after upstream 3) for all

376 seasons (Figure 4a). Significant $(\mathrm{p}<0.05)$ correlations were found between ARG concentrations

377 and E. coli for all months (April $\mathrm{r}=0.710$; May $\mathrm{r}=0.820$; August $\mathrm{r}=0.710$ ). The HF183 marker-

378 which detects faecal Bacteroidales of human origin and can be used as a proxy to measure

379 human faecal pollution (Sauer et al., 2011) decreased throughout wastewater treatment following

380 a similar log reduction as the ARG markers (Figure $4 \mathrm{~b}$ and Figure $2 \mathrm{a}$ for HF183 and total ARGs,

381 respectively). $H F 183$ generally decreased the further the samples were taken upstream, however

382 consistent presence were observed at the UP6 and UP7 sites (Figure 4b), which suggested an 
383 upstream source of human fecal contamination in the watershed, although E. coli levels were low 384 in these samples. There were significant $(\mathrm{p}<0.05)$ correlations between HF183 levels and ARG 385 levels for each month (April $\mathrm{r}=0.879$, May $\mathrm{r}=0.845$, August $\mathrm{r}=0.860$ ). HF183 was the only

386 parameter analyzed that seemed to "peak" in the April samples together with high ARG levels, 387 which indicated that it may be useful in prediction of elevated ARG levels. It is possible that 388 septic systems from nearby unmapped camps or outhouses as well as undocumented human use 389 of the area, could be contributing to human fecal contamination and presence of ARGs in these 390 areas.

3923.5 Correlations between ARGs and antibiotics

393 The concentrations of ABs in water samples from April, May and August of 2016 are 394 provided in Table S3. There were significant positive correlations in April $(\mathrm{r}=0.805, \mathrm{p}<0.05)$ 395 and May $(r=0.906, p<0.05)$ between the total $A B s$ (sum of all antibiotics $(n g / L)$ for each 396 sampling site) and total ARGs (sum of $\log (\operatorname{copies} / \mathrm{mL}$ ) of all ARGs at each sampling site), 397 however there were no significant positive correlations in August. This indicated that when an 398 increased quantity of antibiotics was present in a sample, there generally also seemed to be 399 increased quantities of ARGs, which is not unexpected as ABs can enrich for bacteria which 400 carry ARGs (Martinez, 2009).

401 In order to assess the effect of individual ABs on ARG levels, Pearson correlation 402 analysis was also performed on ARGs and the ABs they confer resistance to (i.e., bla CTX-M, $_{\text {, }}$ $403 \quad b_{T E M}$, and $m e c A$ confer resistance to amoxicillin, cefaclor, cefprozil, and cefdinir; qnrS confers 404 resistance to levofloxacin, and ciprofloxacin; $\operatorname{erm} B$ confers resistance to azithromycin, 405 clindamycin, and clarithromycin) (Jia et al. 2017). In April there were significant correlations 
406 found between $q n r S$ and ciprofloxacin $(\mathrm{r}=0.726, \mathrm{p}<0.05)$, and $\operatorname{ermB}$ and clarithromycin $(\mathrm{r}=0.936$,

$407 \mathrm{p}<0.05)$ when all sampling locations were examined $(\mathrm{n}=10)$; which linked the presence of these

408 ABs and their associated resistance genes. Int1 also had significant correlations with

409 ciprofloxacin $(r=0.684, p<0.05)$ and clarithromycin $(r=0.779, p<0.05)$. Of note, UP2, UP6, and

410 UP7 contained more ABs than the other upstream sites, or even the downstream site. These sites

411 in April often had elevated levels of ARGs, therefore it is possible that increased AB pollution at

412 these sites contributed to increased ARG abundance. Although not significantly correlated,

413 mecA levels were together with cefdinir (a beta-lactam antibiotic, mecA sensitive) elevated in the

414 upstream samples (especially UP2 and UP7) compared to other samples. This is interesting

415 given that mecA was not expected to be found in such high levels in upstream rivers samples,

416 however these spikes in April coincided with high levels of cefdinir. As discussed earlier, the

417 snow melt likely contributed to this sampling event and may have transported ABs into the river

418 that had been preserved during the low temperature season (Dolliver and Gupta, 2008). In May,

419 there were significant $(\mathrm{p}<0.05)$ correlations between bla ${ }_{C T X-M}$, bla $a_{T E M}$, and int1, and amoxicillin

$420 \quad(\mathrm{r}=0.871 ; \mathrm{r}=0.675 ; \mathrm{r}=0831), q n r S$ and ciprofloxacin $(\mathrm{r}=0.963)$, and ermB, int 1 , and azithromycin

$421(\mathrm{r}=0.926 ; \mathrm{r}=0.816)$, which suggested co-occurrences of these ABs and their respective ARGs. In

422 August no significant $(\mathrm{p}>0.05)$ correlations between ARGs and the ABs they confer resistance to

423 were found. There also seemed to be less ABs (besides amoxicillin) detected in the further

424 upstream samples in August compared to the other months, suggesting a seasonal trend with ABs

425 presence or persistence due to altered environmental conditions (e.g., temperatures of $19-22^{\circ} \mathrm{C}$ )

426 in the river. These results also suggested that there are potential sources of ABs in the relatively

427 undeveloped upstream watershed. 


\section{Conclusions}

430 This study assessed the relative impact of the effluent from a tertiary WWTP on the 431 concentration and load of ARGs in a river system draining a largely undeveloped and rural

432 watershed. While meeting strict effluent quality guidelines the WWTP still had a significant

433 impact on ARG levels in the river, although it is not known if and how far downstream the

434 signatures of ARG abundance return to background levels. However, it was found that

435 comparable ARG loads originated from the upstream watershed during wet weather events.

436 These background ARG levels suggest that even areas thought to be undeveloped are likely more

437 affected by anthropogenic activities than originally thought, or that there are larger natural

438 reservoirs of bacteria that harbour ARGs in the environment. The use of additional water quality

439 monitoring tools, such as the human specific HF183 Bacteroidales marker, provided important

440 corroborating evidence of ARG sources in this watershed.

4425 Acknowledgements

443 We would like to thank the Municipality of Kings County and the staff at Greenwood's

444 wastewater treatment facility. We would also like to thank our team members for their

445 assistance in the field and laboratory (Audrey Hiscock, Robert Johnson, and Amy Jackson,

446 Huryyah Alamer, and Katharine Miller). Funding for this project was provided by the Natural

447 Science and Engineering Research Council of Canada (STPGP 463352 - 14).

References 
Baltz, R. H., 2008. Renaissance in antibacterial discovery from actinomycetes. Curr. Opin. Pharmacol. 8, 557-563.

Barraud, O., Baclet, M.C., Denis, F., Ploy, M.C., 2010. Quantitative multiplex real-time PCR for detecting class 1, 2 and 3 integrons. J. Antimicrob. Chemother. 65, 1642-1645.

Berglund, B., Fick, J., Lindgren, P.E., 2015., Urban wastewater effluent increases antibiotic resistance gene concentrations in a receiving northern European river. Environ. Toxicol. Chem. 34, 192-196. doi:10.1002/etc. 2784

\section{Bio-Rad, 2013. CFX384 / CFX96 Touch TM Real-Time PCR Detection Systems Instruction Manual, Manual.}

Böckelmann, U., Dörries, H., Ayuso-Gabella, M.N., Salgot de Marçay, M., Tandoi, V., Levantesi, C., Masciopinto, C., Van Houtte, E., Szewzyk, U., Wintgens, T., Grohmann, E., 2009. Quantitative PCR monitoring of antibiotic resistance genes and bacterial pathogens in three European artificial groundwater recharge systems. Appl. Environ. Microbiol. 75, 154-163.

Brankatschk, R., Bodenhausen, N., Zeyer, J., Burgmann, H., 2012. Simple absolute quantification method correcting for quantitative PCR efficiency variations for microbial community samples. Appl. Environ. Microbiol. 78, 4481-4489. doi:10.1128/AEM.0787811

Chen, H., Zhang, M., 2013. Effects of advanced treatment systems on the removal of antibiotic resistance genes in aastewater treatment plants from Hangzhou, China. Environ. Sci. Technol. 47, 8157-8163.

Colomer-Lluch, M., Jofre, J., Muniesa, M., 2011. Antibiotic resistance genes in the bacteriophage DNA fraction of environmental samples. PLoS ONE 6, e17549. http://dx.doi. org/10.1371/journal.pone.0017549.

Colomer-Lluch, M., Jofre, J., Muniesa, M., 2014. Quinolone resistance genes (qnrA and qnrS) bacteriophage particles from wastewater samples and the effect of inducing agents on packaged antibiotic resistance genes. J. Antimicrob. Chemother. 69, 1265-1274.

Czekalski, N., Berthold, T., Caucci, S., Egli, A., Bürgmann, H., 2012. Increased levels of multiresistant bacteria and resistance genes after wastewater treatment and their dissemination into Lake Geneva, Switzerland. Front. Microbiol. 3:106. http://dx.doi. org/10.3389/fmicb.2012.00106. 
496

497

498

499

500

501

502

503

504

505

506

507

508

509

510

511

512

513

514

515

516

517

518

519

520

521

522

523

524

525

526

527

528

529

530

531

532

533

534

535

536

537

538

539

540

Davies, J., Davies, D., 2010. Origins and evolution of antibiotic resistance. Microbiol. Mol. Biol. Rev. 74, 417-433. doi:10.1128/MMBR.00016-10

Dingman, S.L., 2002. Physical Hydrology. Second edition. Waveland Press Inc. Long Grove, Illinois, United States.

Dolliver, H., Gupta, S., 2008. Antibiotic losses in leaching and surface runoff from manureamended agricultural land. J. Environ. Qual. 37, 1227-1237.

Francois, P., Pittet, D., Bento, M., Pepey, B., Vandaux, P., Lew, D., Schrenzel, J., 2003. Rapid detection of methicillin-resistant Staphylococcus aureus directly from sterile or nonsterile clinical samples by a new molecular assay. J. Clin. Microbiol. 41, 254-260.

Freeman, C. N., Scriver, L., Neudorf, K.D., Truelstrup Hansen, L., Jamieson, R.C., Yost, C.K. 2017. Antimicrobial resistance gene surveillance in the receiving waters of an upgraded wastewater treatment plant. FACETS doi: 10.1139/facets-2017-0085

Gao, P., He, S., Huang, S., Li, K., Liu, Z., Xue, G., Sun, W., 2015. Impacts of coexisting antibiotics, antibacterial residues, and heavy metals on the occurrence of erythromycin resistance genes in urban wastewater. Appl. Microbiol. Biotechnol. 99, 3971-3980. doi:10.1007/s00253-015-6404-9

Government of Nova Scotia (2006). Enhanced digital elevation model, Nova Scotia, Canada. DP ME 55, Version2. Retrieved online from: https://novascotia.ca/natr/meb/download/dp055.asp [November 3, 2017].

Government of Canada (2016a). Wooded areas, saturated soils and landscape in Canada CanVec series - Land features. Natural Resources Canada. Retrieved online from: http://open.canada.ca/data/en/dataset/80aa8ec6-4947-48de-bc9c-7d09d48b4cad [November 2, 2017].

Government of Canada (2016b). Constructions and land use in Canada - CanVec seriesManmade features. Natural Resources Canada. Retrieved online from: http://open.canada.ca/data/en/dataset/fd4369a4-21fe-4070-914a-067474da0fd6 [November 2, 2017].

Haugland, R.A., Varma, M., Sivaganesan, M., Kelty, C., Preed, L., Shanks, O.C., 2010. Evaluation of genetic markers from the $16 \mathrm{~S}$ rRNA gene V2 region for use in quantitative detection of selected Bacteroidales species and human fecal waste by qPCR. Syst Appl Microbiol. 33, 348-357.

Heurer, H., Focks, A., Lamshöft, M., Smalla, K., Matthies, M., Spiteller, M., 2008. Fate of sulfadiazine administered to pigs and its quantitative effect on the dynamics of bacterial resistance genes in manure and manured soil. Soil Biol. Biochem. 40, 1892-1900. 
Jia et al. 2017. CARD 2017: Expansion and model-centric curation of the Comprehensive Antibiotic Resistance Database. Nucleic Acids Res. 45, D566-573.

Katayama, Y., Ito, T., Hiramatsu, K., 2000. A new class of genetic element, Staphylococcus cassette chromosome mec, encodes methicillin resistance in Staphylococcus aureus. Antimicrob. Agents Chemother. 44(6), 1549-1555.

Knapp, C.W., Lima, L., Olivares-Rieumont, S., Bowen, E., Werner, D., Graham, D.W., 2012. Seasonal variations in antibiotic resistance gene transport in the Almendares River, Havana, Cuba. Front. Microbiol. 3, 1-11. doi:10.3389/fmicb.2012.00396

Lachmayr, K.L., Kerkhof, L.J., DiRienzo, A.G., 2008. Quantifying nonspecific TEM $\beta$ lactamase (blaTEM) genes in a wastewater stream. Appl. Environ. Microbiol. 75, 203-211.

Laht, M., Karkman, A., Voolaid, V., Ritz, C., Tenson, T., Virta, M., Kisand, V., 2014. Abundances of tetracycline, sulphonamide and beta-lactam antibiotic resistance genes in conventional wastewater treatment plants (WWTPs) with different waste load. PLoS One, 9, 1-8. doi:10.1371/journal.pone.0103705

Layton, B.A., Cao, Y., Ebentier, D.L., Griffith, J.F., 2013. Performance of human fecal anaerobe-associated PCR-based assays in a multi-laboratory method evaluation study. Water Res. 47, 6897-6908.

Makowska, N., Koczura, R., Mokracka, J., 2016. Class 1 integrase, sulfonamide and tetracycline resistance genes in wastewater treatment plant and surface water. Chemosphere. 144, 16651673. doi:10.1016/j.chemosphere.2015.10.044

Martinez, J.L., 2009. Environmental pollution by antibiotics and by antibiotic resistance determinants. Environ. Pollut. 157, 2893-2902. doi:10.1016/j.envpol.2009.05.051

Munir, M., Wong, K., Xagoraraki, I., 2011. Release of antibiotic resistant bacteria and genes in the effluent and biosolids of five wastewater utilities in Michigan. Water Res. 45, 681-693. doi:10.1016/j.watres.2010.08.033

Nesme, J., Cécillon, S., Delmont, T.O., Monier, J-M., Vogel T.M., Simonet, P., 2014. Largescale metagenomic-based study of antibiotic resistance in the environment. Curr Biol. 24(10), 1096-1100.

Neudorf, K., Huang, Y.N., Ragush, C., Yost, C., Jamieson, R., Truelstrup Hansen, L., 2017. Antibiotic resistance genes in municipal wastewater treatment systems and receiving waters in Arctic Canada. Sci Total Environ. 598, 1085-1094.

Norman, A., Hansen, L.H., Sorensen, S.J., 2009. Conjugative plasmid: vessels of the communal gene pool. Phil. Trans. R. Soc. B. 364, 2275-2289. 
Ouyang, W.Y., Huang, F.Y., Zhao, Y., Li, H., Su, J.Q., 2015. Increased levels of antibiotic resistance in urban stream of Jiulongjiang River, China. Appl. Microbiol. Biotechnol. 99, 5697-5707. doi:10.1007/s00253-015-6416-5

Proia, L., Von Schiller, D., Sànchez-Melsió, A., Sabater, S., Borrego, C.M., Rodríguez-Mozaz, S., Balcázar, J.L., 2016. Occurrence and persistence of antibiotic resistance genes in river biofilms after wastewater inputs in small rivers. Environ. Pollut. 210, 121-128. doi:10.1016/j.envpol.2015.11.035

Pruden, A., Pei, R., Storteboom, H., Carlson, K.H., 2006. Antibiotic resistance genes as emerging contaminants: Studies in northern Colorado. Environ. Sci. Technol. 40, 74457450. doi:10.1021/es0604131

Rahube, T.O., Marti, R., Scott, A., Tien, Y., Murray, R., Sabourin, L., Zhang, Y., Duenk, P., Lapen, D.R., Topp, E., 2014. Impact of fertilizing with raw or anaerobically digested sewage sludge on the abundance of antibiotic-resistant coliforms, antibiotic resistant genes, and pathogenic bacteria in soil and on vegetables at harvest. Appl. Environ.Microbiol. 80, 6898-6907.

Rodriguez-Mozaz, S., Chamorro, S., Marti, E., Huerta, B., Gros, M., Sànchez-Melsió, A., Borrego, C.M., Barceló, D., Balcázar, J.L., 2015. Occurrence of antibiotics and antibiotic resistance genes in hospital and urban wastewaters and their impact on the receiving river. Water Res. 69, 234-242. doi:10.1016/j.watres.2014.11.021

Ruijter, J.M., Ramakers, C., Hoogaars, W.M.H., Karlen, Y., Bakker, O., Van Den Hoff, M.J.B., Moorman, A.F.M., 2009. Amplification efficiency: Linking baseline and bias in the analysis of quantitative PCR data. Nucleic Acids Res. 37. doi:10.1093/nar/gkp045

Salyers, A.A., Amábile-Cuevas, C.F., 1997. Why are antibiotic resistance genes so resistant to elimination? Antimicrob. Agents Chemother. 41, 2321-2325.

Sauer, E.P., VandeWalle, J.L., Bootsma, M.J., McLellan, S.L., 2011. Detection of the human specific Bacteroides genetic marker provides evidence of widespread sewage contamination of stormwater in the urban environment. Water Res. 45, 4081-4091. doi:10.1016/j.watres.2011.04.049

Statistics Canada., 2011. Pictou, Subd. C, Nova Scotia (Code 1212011) and Canada (Code 01) (table). Census Profile. Catalogue no. 98-316-XWE. Ottawa. Released October 24, 2012. Retrieved from http://www12.statcan.gc.ca/census-recensement/2011/dppd/prof/index.cfm?Lang=E (accessed February 17, 2017).

Storteboom, H., Arabi, M., Davis, J.G., Crimi, B., Pruden, A., 2010. Identification of antibioticresistance-gene molecular signatures suitable as tracers of pristine River, urban, and 
Suzuki, M.T., Taylor, L.T., DeLong, E.F., 2000. Quantitative analysis of small-subunit rRNA genes in mixed microbial populations via 5'-nuclease assays. Appl. Environ. Microbiol. 66, $4605-4614$.

Szczepanowski, R., Linke, B., Krahn, I., Gartemann, K.H., Gützkow, T., Eichler, W., Pühler, A., Schlüter, A., 2009. Detection of 140 clinically relevant antibiotic-resistance genes in the plasmid metagenome of wastewater treatment plant bacteria showing reduced susceptibility to selected antibiotics. Microbiology. 155, 2306-2319. doi:10.1099/mic.0.028233-0

Toleman, M.A., Bennett, P.M., Walsh, T.R., 2006. Common regions e.g. orf513 and antibiotic resistance: IS91-like elements evolving complex class 1 integrons. J. Antimicrob. Chemother. 58, 1-6. doi:10.1093/jac/dk1204

\section{Volkmann, H., Schwartz, T., Bischoff, P., Kirchen, S., Obst, U., 2004. Detection of clinically} relevant antibiotic-resistance genes in municipal wastewater using real-time PCR (TaqMan). J. Microbiol. Methods 56, 277-286. doi:10.1016/j.mimet.2003.10.014 


\section{Figure Captions}

652 Figure 1. Map of WWTP and watershed sampling locations detailing land use in the area.

653 Sampling locations are labeled as I and E (influent and effluent), D (downstream), and UP1 to 654 UP7 (Upstream 1 to Upstream 7).

656 Figure 2. Box plots (minimum to maximum concentrations of all ARGs as well as int 1 ) showing 657 seasonal and locational patterns of (a) ARG markers (absolute abundances log (gene copies $/ \mathrm{mL}$ ) 658 in the influent, effluent, and river samples from April, May, and August 2016. 16S rRNA log 659 (gene copies $/ \mathrm{mL}$ ) levels are also shown (filled circles); and (b) ARG loading (log copies/sec) in 660 the influent, effluent, and river samples obtained downstream and upstream from the WWTP. In 661 each plot, the dots represent each ARG marker, while lines represent the median log gene 662 copies $/ \mathrm{mL}$ of each sampling location. Samples below the LOQ for each ARG were set to $1 / 2$ 663 LOQ.

665 Figure 3. Seasonal absolute abundances $(\log (\operatorname{copies} / \mathrm{mL}))$ for ARGs in the influent (I) and 666 effluent (E) from the WWTP and river water samples obtained downstream (D) and upstream 667 (UP) of the WWTP. Samples below the LOQ (shown as a red dashed line) for each ARG were 668 set to $1 / 2$ LOQ. Samples below LOD were set to $1 / 2 \operatorname{LOD}(-0.30$ log units) for river samples).

670 Figure 4. Content of fecal indicator markers in influent and effluent samples from the WWTP 671 and in river water samples downstream and upstream from the discharge point showing: a) $E$.

672 coli values on April, May and August 2016 (LOD $1 \mathrm{MPN} / 100 \mathrm{~mL}$ ), and b) HF183 human

673 Bacteroidales marker on April, May and August 2016. HF183 values were corrected if below 
674 the LOQ (values $<$ LOQ set to $1 / 2 \mathrm{LOQ}$ ). Samples that appear not to have a bar are $<$ LOD and 675 therefore contained $<0.5$ HF 183 copies $/ \mathrm{mL}$ or less.

676

677

678 
679 Tables

680 Table 1. Description of sampling sites and land use of their corresponding drainage areas.

\begin{tabular}{|c|c|c|c|c|c|c|c|c|c|c|c|}
\hline \multirow[t]{2}{*}{$\begin{array}{l}\text { Sample } \\
\text { location }\end{array}$} & \multirow{2}{*}{$\begin{array}{l}\text { Sample } \\
\text { collection } \\
\text { dates }\end{array}$} & \multirow{2}{*}{$\begin{array}{l}\text { Drainage } \\
\text { area }\end{array}$} & \multicolumn{2}{|c|}{$\begin{array}{l}\text { Forest including } \\
\text { wetland }\end{array}$} & \multicolumn{2}{|c|}{ Agriculture } & \multicolumn{2}{|c|}{ Wetland } & \multicolumn{2}{|c|}{ Lakes } & \multirow[t]{2}{*}{$\begin{array}{l}\# \text { of } \\
\text { residences }\end{array}$} \\
\hline & & & $\mathbf{k m}^{2}$ & $\begin{array}{l}\% \text { of } \\
\text { total }\end{array}$ & $\mathbf{k m}^{2}$ & $\begin{array}{l}\% \text { of } \\
\text { total }\end{array}$ & $\mathbf{k m}^{2}$ & $\begin{array}{l}\text { \% of } \\
\text { total }\end{array}$ & $\mathbf{k m}^{2}$ & $\begin{array}{l}\text { \% of } \\
\text { total }\end{array}$ & \\
\hline $\begin{array}{l}\begin{array}{l}\text { Outlet } \\
\text { (include }\end{array} \\
\text { I, E, D, } \\
\text { UP1) }\end{array}$ & $\begin{array}{l}\text { Aug.18/ } \\
2015, \\
\text { Feb.23, } \\
\text { Apr.12, } \\
\text { May 10, } \\
\text { Aug.2/ } \\
2016\end{array}$ & 116 & 106 & 91.8 & 2.1 & 1.8 & 3.7 & 3.2 & 3.8 & 3.3 & 223 \\
\hline UP2 & $\begin{array}{l}\text { Apr.12, } \\
\text { May 10, } \\
\text { Aug. } 2 \\
\text { /2016 }\end{array}$ & 114 & 106 & 92.6 & 1.8 & 1.6 & 3.7 & 3.2 & 3.8 & 3.4 & 81 \\
\hline UP3 & $\begin{array}{l}\text { Apr.12, } \\
\text { May 10, } \\
\text { Aug.2/ } \\
2016\end{array}$ & 111 & 104 & 94.1 & 0.5 & 0.5 & 3.7 & 3.3 & 3.8 & 3.5 & 41 \\
\hline UP4 & $\begin{array}{l}\text { Apr.12, } \\
\text { May 10, } \\
\text { Aug.2/ } \\
2016\end{array}$ & 109 & 103 & 94.6 & 0.4 & 0.4 & 3.7 & 3.4 & 3.8 & 3.5 & 21 \\
\hline UP5 & $\begin{array}{l}\text { Apr.12, } \\
\text { May 10, } \\
\text { Aug.2/ } \\
2016\end{array}$ & 46 & 44 & 95.4 & 0.0 & 0.0 & 1.9 & 4.0 & 2.0 & 4.3 & 2 \\
\hline UP6 & $\begin{array}{l}\text { Apr.12, } \\
\text { May 10, } \\
\text { Aug.2/ } \\
2016\end{array}$ & 3.9 & 3.7 & 93.7 & 0.1 & 1.8 & 0.1 & 1.9 & 0.0 & 0.0 & 1 \\
\hline UP7 & $\begin{array}{l}\text { Apr.12, } \\
\text { May 10, } \\
\text { Aug.2/ } \\
2016\end{array}$ & 12 & 11 & 98.9 & 0.0 & 0.0 & 1.3 & 11 & 0.1 & 0.9 & 0 \\
\hline
\end{tabular}


683 Figures

684

685

686

687

688

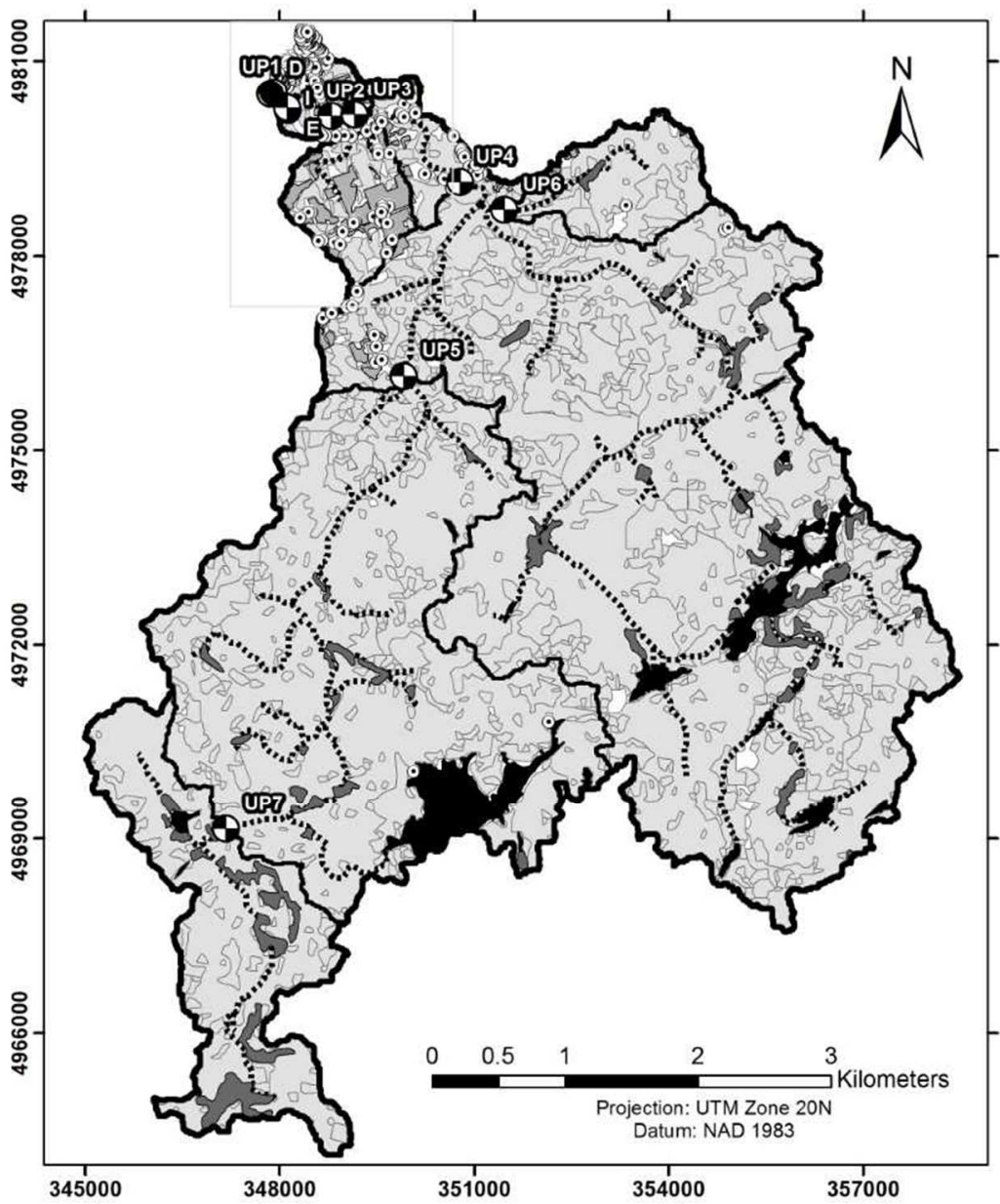

Figure 1
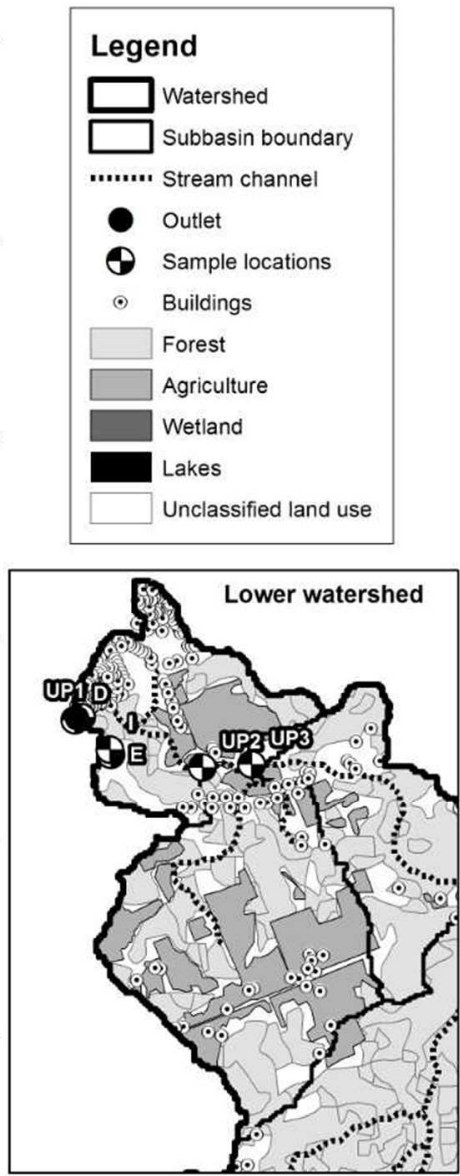

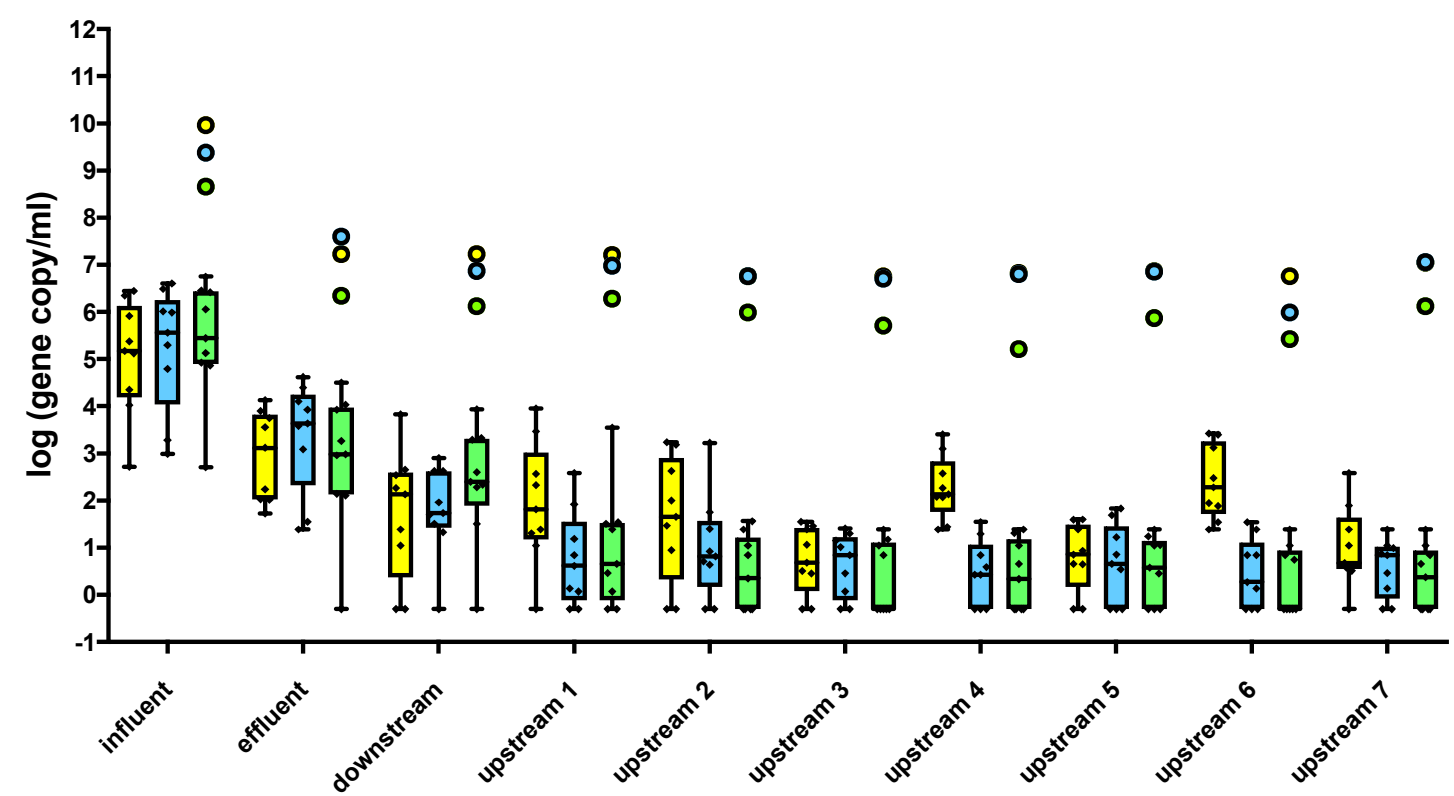

691

b)

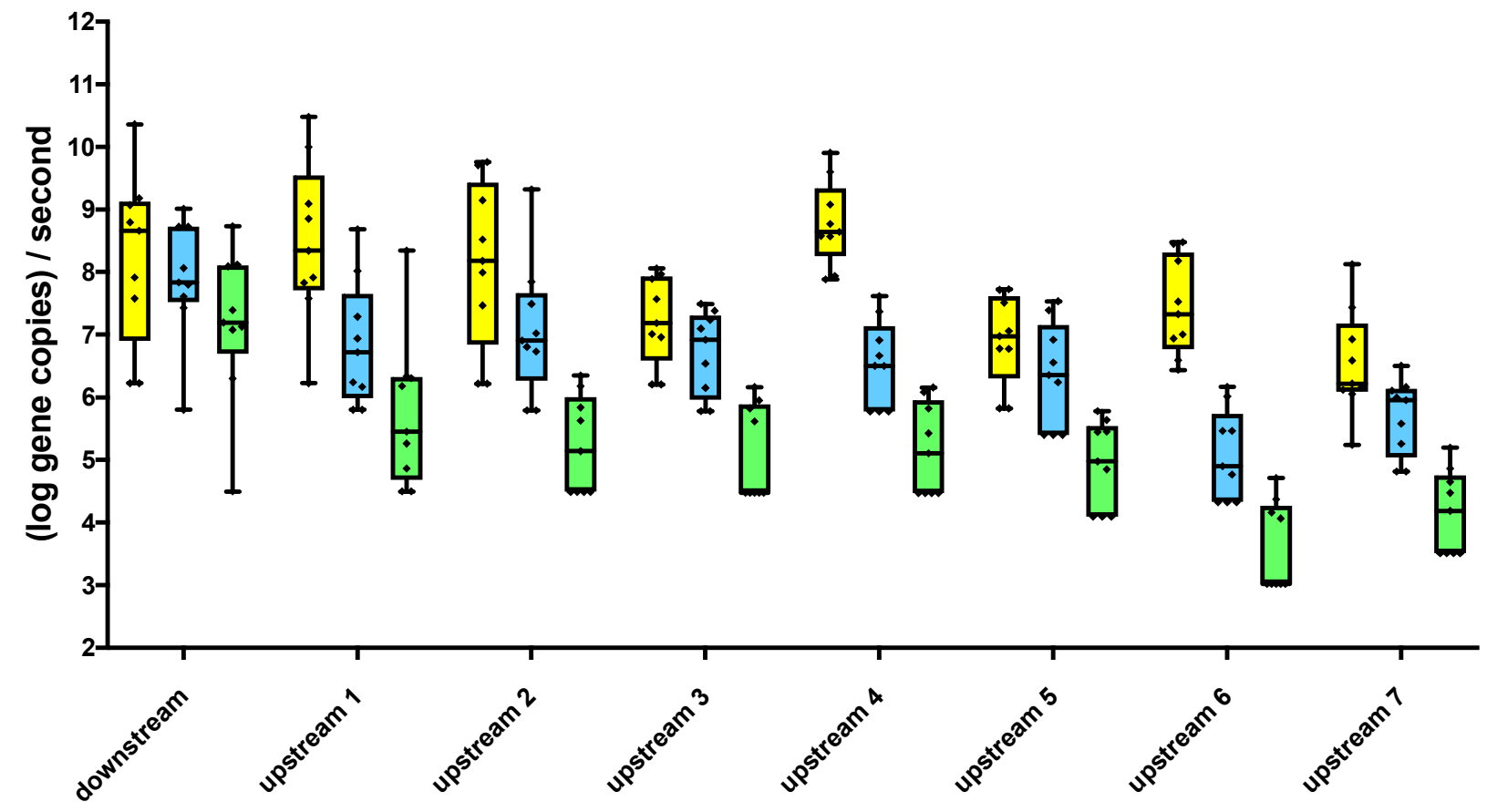

693 Figure 2 

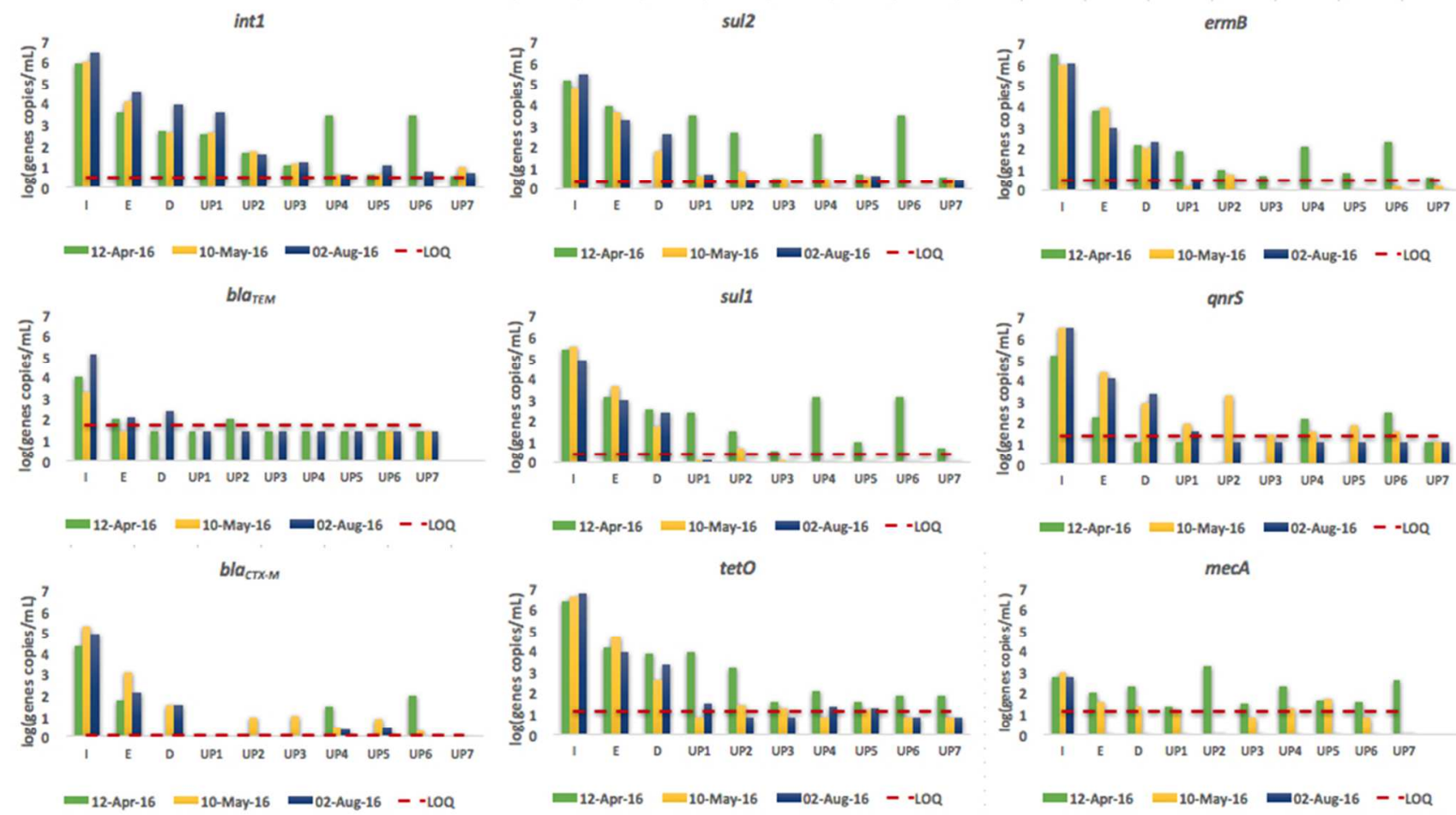

696 Figure 3

697

698 
700

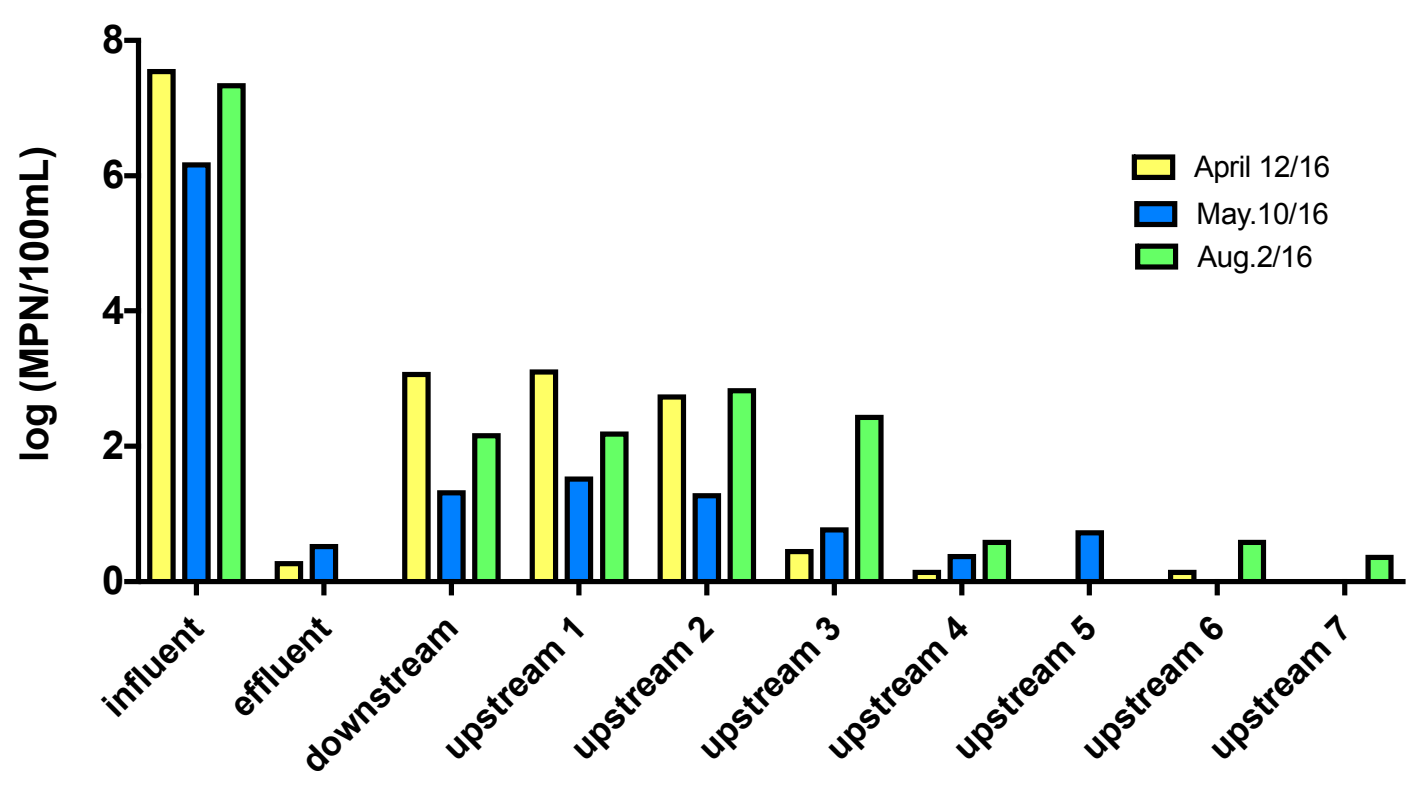

701 b)

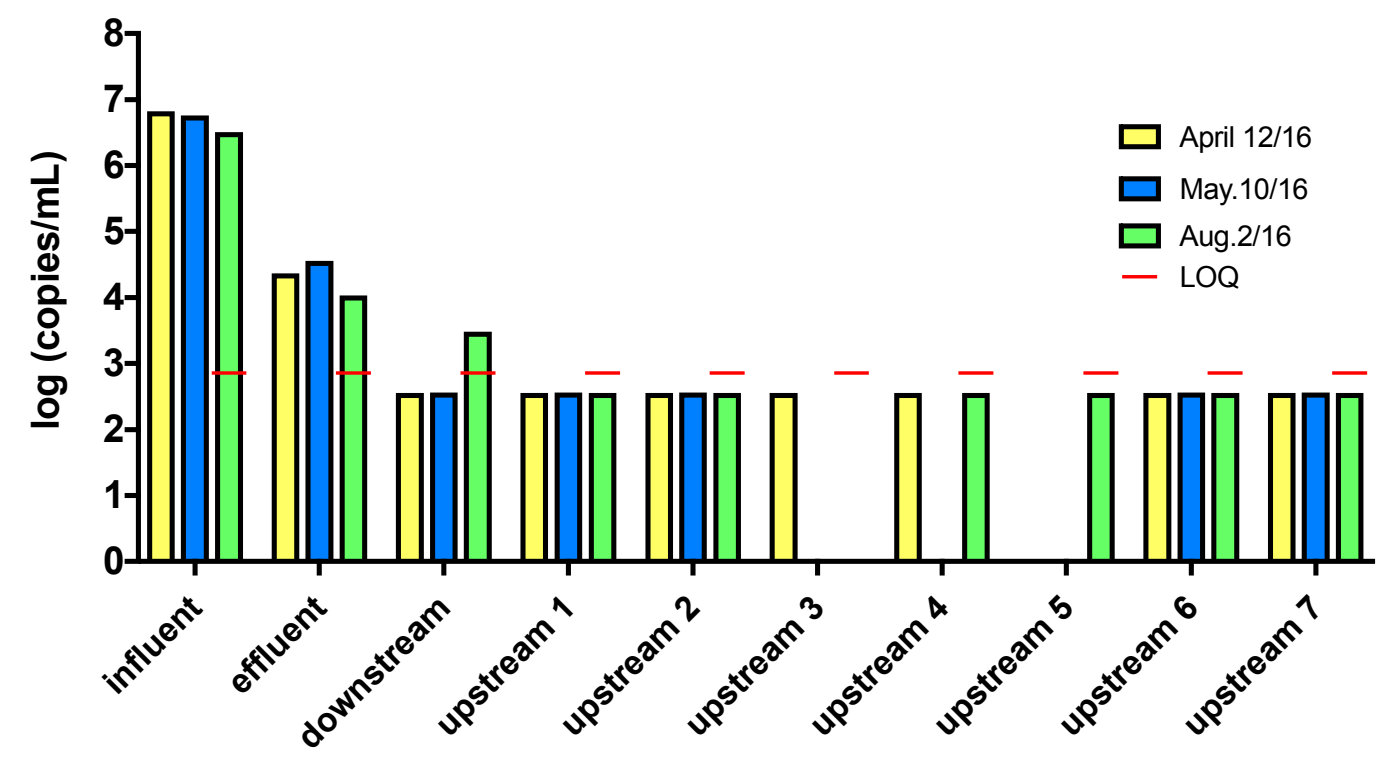

703 Figure 4.

704

705

706

707

708 
Table S1. Quantitative PCR primer sequences and reaction conditions

\begin{tabular}{|c|c|c|c|c|}
\hline Target gene & Primer & Sequence $\left(5^{\prime}-3^{\prime}\right)$ & Conditions & Reference \\
\hline 16S rRNA & $\begin{array}{l}1369 \mathrm{~F} \\
1492 \mathrm{R}\end{array}$ & $\begin{array}{l}\text { CGGTGAATACGTTCYCGG } \\
\text { GGWTACCTTGTTACGACTT }\end{array}$ & $\begin{array}{l}95^{\circ} \mathrm{C} \text { for } 10 \\
\text { mins; } 40 \text { cycles } \\
\text { of } 95^{\circ} \mathrm{C} \text { for } 15 \mathrm{~s} \text {, } \\
55^{\circ} \mathrm{C} \text { for } 30 \mathrm{~s} \text {, } \\
\text { and } 72^{\circ} \mathrm{C} \text { for } \\
30 \mathrm{~s}\end{array}$ & $\begin{array}{l}\text { Suzuki et al., } \\
2000\end{array}$ \\
\hline $\operatorname{erm}(B)$ & $\begin{array}{l}\text { ermBF } \\
\text { ermBR } \\
\text { ermBP }\end{array}$ & $\begin{array}{l}\text { GGATTCTACAAGCGTACCTTGGA } \\
\text { GCTGGCAGCTTAAGCAATTGCT } \\
\text { FAM-CACTAGGGTTGCTCTTGCACACTCAAGTCBHQ-1 }\end{array}$ & $\begin{array}{l}95^{\circ} \mathrm{C} \text { for } 3 \mathrm{~min} ; \\
40 \text { cycles of } \\
95^{\circ} \mathrm{C} \text { for } 15 \mathrm{~s}, \\
62^{\circ} \mathrm{C} \text { for } 30 \mathrm{~s}\end{array}$ & Böckelmann et al., 2009 \\
\hline $\operatorname{Mec} A$ & $\begin{array}{l}\text { mecAF } \\
\text { mecAR } \\
\text { mecAP }\end{array}$ & $\begin{array}{l}\text { CATTGATCGCAACGTTCAATTTAAT } \\
\text { TGGTCTTTCTGCATTCCTGGA } \\
\text { FAM-CTATGATCCCAATCTAACTTCCACATACCBHQ-1 }\end{array}$ & $\begin{array}{l}95^{\circ} \mathrm{C} \text { for } 3 \mathrm{~min} ; \\
40 \text { cycles of } \\
95^{\circ} \mathrm{C} \text { for } 15 \mathrm{~s}, \\
62^{\circ} \mathrm{C} \text { for } 30 \mathrm{~s}\end{array}$ & $\begin{array}{l}\text { Böckelmann et al., } \\
2009 ; \\
\text { Francois et al., } \\
2003\end{array}$ \\
\hline tetO & $\begin{array}{l}\text { tetOF } \\
\text { tetOR } \\
\text { tetOP }\end{array}$ & $\begin{array}{l}\text { AAGAAAACAGGAGATTCCAAAACG } \\
\text { CGAGTCCCCAGATTGTTTTTAGC } \\
\text { FAM-ACGTTATTTCCCGTTTATCACGGAAGCG-BHQ-1 }\end{array}$ & $\begin{array}{l}95^{\circ} \mathrm{C} \text { for } 3 \mathrm{~min} ; \\
40 \text { cycles of } \\
95^{\circ} \mathrm{C} \text { for } 15 \mathrm{~s}, \\
62^{\circ} \mathrm{C} \text { for } 30 \mathrm{~s}\end{array}$ & $\begin{array}{l}\text { Böckelmann et } \\
\text { al., } 2009\end{array}$ \\
\hline bla $_{C T X-M}$ & $\begin{array}{l}B L A C T X-M \mathrm{UP} \\
B L A C T X-M \text { LP } \\
\text { CTX-probe }\end{array}$ & $\begin{array}{l}\text { ACCAACGATATCGCGGTGAT } \\
\text { ACATCGCGACGGCTTTCT } \\
\text { FAM-TCGTGCGCCGCTG-BHQ1 }\end{array}$ & $\begin{array}{l}95^{\circ} \mathrm{C} \text { for } 3 \mathrm{~min} ; \\
40 \text { cycles of } \\
95^{\circ} \mathrm{C} \text { for } 15 \mathrm{~s}, \\
62^{\circ} \mathrm{C} \text { for } 30 \mathrm{~s}\end{array}$ & $\begin{array}{l}\text { Colomer- } \\
\text { Lluch et al., } \\
2011\end{array}$ \\
\hline bla $_{T E M}$ & $\begin{array}{l}\text { TEM UP } \\
\text { TEM LP } \\
\text { TEM Probe }\end{array}$ & $\begin{array}{l}\text { CACTATTCTCAGAATGACTTGGT } \\
\text { TGCATAATTCTCTTACTGTCATG } \\
\text { FAM-CCAGTCACAGAAAAGCATCTTACGG-BHQ1 }\end{array}$ & $\begin{array}{l}95^{\circ} \mathrm{C} \text { for } 3 \mathrm{~min} ; \\
40 \text { cycles of } \\
95^{\circ} \mathrm{C} \text { for } 15 \mathrm{~s}, \\
62^{\circ} \mathrm{C} \text { for } 30 \mathrm{~s}\end{array}$ & $\begin{array}{l}\text { Lachmayr et } \\
\text { al., } 2008\end{array}$ \\
\hline sul1 & $\begin{array}{l}\text { qSUL653f } \\
\text { qSUL719r } \\
\text { tpSUL1 }\end{array}$ & $\begin{array}{l}\text { CCGTTGGCCTTCCTGTAAAG } \\
\text { TTGCCGATCGCGTGAAGT } \\
\text { FAM -CAGCGAGCCTTGCGGCGG-BHQ1 }\end{array}$ & $\begin{array}{l}95^{\circ} \mathrm{C} \text { for } 3 \mathrm{~min} ; \\
40 \text { cycles of } \\
95^{\circ} \mathrm{C} \text { for } 15 \mathrm{~s}, \\
62^{\circ} \mathrm{C} \text { for } 30 \mathrm{~s}\end{array}$ & $\begin{array}{l}\text { Czekalshi et } \\
\text { al., 2012; } \\
\text { Heuer et al., } \\
2008 \\
\end{array}$ \\
\hline sul2 & $\begin{array}{l}\text { qSUL2_595f } \\
\text { qSUL2_654r } \\
\text { tpSUL2_614 }\end{array}$ & $\begin{array}{l}\text { CGGCTGCGCTTCGATT } \\
\text { CGCGCGCAGAAAGGATT } \\
\text { FAM -CGGTGCTTCTGTCTGTTTCGCGC-BHQ1 }\end{array}$ & $\begin{array}{l}95^{\circ} \mathrm{C} \text { for } 3 \mathrm{~min} ; \\
40 \text { cycles of } \\
95^{\circ} \mathrm{C} \text { for } 15 \mathrm{~s}, \\
62^{\circ} \mathrm{C} \text { for } 30 \mathrm{~s}\end{array}$ & $\begin{array}{l}\text { Czekalshi et } \\
\text { al., 2012; } \\
\text { Heuer et al., } \\
2008\end{array}$ \\
\hline$q n r S$ & $\begin{array}{l}\text { qnrS UP } \\
q n r S \text { LP } \\
q n r S \text { probe }\end{array}$ & $\begin{array}{l}\text { CGACGTGCTAACTTGCGTGA } \\
\text { GGCATTGTTGGAAACTTGCA } \\
\text { FAM -AGTTCATTGAACAGGGTGA-BHQ1 }\end{array}$ & $\begin{array}{l}95^{\circ} \mathrm{C} \text { for } 3 \mathrm{~min} ; \\
40 \text { cycles of } \\
95^{\circ} \mathrm{C} \text { for } 15 \mathrm{~s}, \\
62^{\circ} \mathrm{C} \text { for } 30 \mathrm{~s}\end{array}$ & $\begin{array}{l}\text { Colomer- } \\
\text { Lluch et al., } \\
2014\end{array}$ \\
\hline $\operatorname{Van} A$ & $\begin{array}{l}\text { vanAF } \\
\text { vanAR } \\
\text { vanAP }\end{array}$ & $\begin{array}{l}\text { CTGTGAGGTCGGTTGTGCG } \\
\text { TTTGGTCCACCTCGCCA } \\
\text { FAM-CAACTAACGCGGCACTGTTTCCCAAT-BHQ-1 }\end{array}$ & $\begin{array}{l}95^{\circ} \mathrm{C} \text { for } 3 \mathrm{~min} \\
40 \text { cycles of } \\
95^{\circ} \mathrm{C} \text { for } 15 \mathrm{~s}, \\
62^{\circ} \mathrm{C} \text { for } 30 \mathrm{~s}\end{array}$ & Volkmann et al., 2004 \\
\hline int1 & $\begin{array}{l}\text { intI1-LC1 } \\
\text { intI1-LC5 } \\
\text { intI1-probe }\end{array}$ & $\begin{array}{l}\text { GCCTTGATGTTACCCGAGAG } \\
\text { GATCGGTCGAATGCGTGT } \\
\text { FAM-ATTCCTGGCCGTGGTTCTGGGTTTT-BHQ1 }\end{array}$ & $\begin{array}{l}95^{\circ} \mathrm{C} \text { for } 3 \mathrm{~min} \\
40 \text { cycles of } \\
95^{\circ} \mathrm{C} \text { for } 15 \mathrm{~s}, \\
62^{\circ} \mathrm{C} \text { for } 30 \mathrm{~s}\end{array}$ & $\begin{array}{l}\text { Barraud et al., } \\
2010\end{array}$ \\
\hline HF183 & $\begin{array}{l}\text { HF183-F } \\
\text { HF183-R } \\
\text { HF183-p }\end{array}$ & $\begin{array}{l}\text { ATCATGAGTTCACATGTCCG } \\
\text { CTTCCTCTCAGAACCCCTATCC } \\
\text { CTAATGGAACGCATCCC }\end{array}$ & $\begin{array}{l}95^{\circ} \mathrm{C} \text { for } 3 \mathrm{~min} ; \\
40 \text { cycles of } \\
95^{\circ} \mathrm{C} \text { for } 30 \mathrm{~s}, \\
58^{\circ} \mathrm{C} \text { for } 30 \mathrm{~s}\end{array}$ & $\begin{array}{l}\text { Haugland et al., 2010; } \\
\text { Layton et al., } 2013\end{array}$ \\
\hline
\end{tabular}


714 Table S2. Average and maximum effluent water quality from sampling events ( $\mathrm{n}=5$, August 18

7152015 and February 23, April 12, May 10, August 2 2016)

\begin{tabular}{lll}
\hline Parameter & Average & Max \\
\hline $\mathrm{CBOD}_{5}(\mathrm{mg} / \mathrm{L})$ & 2.051 & 3.64 \\
$\mathrm{TSS}(\mathrm{mg} / \mathrm{L})$ & 1.225 & 1.6 \\
$\mathrm{VSS}(\mathrm{mg} / \mathrm{L})$ & 0.913 & 20.00 \\
$\mathrm{COD}(\mathrm{mg} / \mathrm{L})$ & 13.68 & 27.2 \\
$\mathrm{TN}(\mathrm{mg} / \mathrm{L})$ & 16.08 & 8.5 \\
$\mathrm{TP}(\mathrm{mg} / \mathrm{L})$ & 2.84 & 16.9 \\
Nitrate $(\mathrm{mg} / \mathrm{L})$ & 11.58 & 0.887 \\
Ammonia $(\mathrm{mg} / \mathrm{L})$ & 0.414 & 2.273 \\
Total coliforms $(\mathrm{MPN} / 100 \mathrm{~mL})$ & 1.304 & 0.556 \\
E. coli $\log (\mathrm{MPN} / 100 \mathrm{~mL})$ & 0.363 & \\
\hline
\end{tabular}

716

717 
718 Table S3. Antibiotics detected in samples (ng/L) in water samples obtained on April 12, May 10,

719 and August 2, 2016.

\begin{tabular}{|c|c|c|c|c|c|c|c|c|c|c|}
\hline Sample & $\begin{array}{l}\text { Month } \\
\text { (2016) }\end{array}$ & $\begin{array}{l}\text { Amox- } \\
\text { icillin }\end{array}$ & $\begin{array}{l}\text { Cefa- } \\
\text { clor }\end{array}$ & $\begin{array}{l}\text { Cef- } \\
\text { dinir }\end{array}$ & $\begin{array}{l}\text { Levo- } \\
\text { floxacin }\end{array}$ & $\begin{array}{l}\text { Cipro- } \\
\text { floxacin }\end{array}$ & $\begin{array}{l}\text { Azithro- } \\
\text { mycin }\end{array}$ & $\begin{array}{l}\text { Clinda- } \\
\text { mycin }\end{array}$ & $\begin{array}{l}\text { Clarithro- } \\
\text { mycin }\end{array}$ & $\begin{array}{l}\text { Triclo- } \\
\text { carban }\end{array}$ \\
\hline $\begin{array}{l}\text { April MDL } \\
\text { (ng/L) }\end{array}$ & & 16 & 542 & 50 & 28 & 63 & 39 & 1 & 1 & 28 \\
\hline $\begin{array}{l}\text { May/August } \\
\text { MDL (ng/L) }\end{array}$ & & 35 & 29 & 95 & 91 & 71 & 40 & 30 & 74 & 50 \\
\hline \multirow[t]{3}{*}{ Influent } & April & $<\mathrm{DL}$ & $<\mathrm{DL}$ & $<\mathrm{DL}$ & 156 & 2246 & 196 & 13 & 406 & 48 \\
\hline & May & 3949 & $<\mathrm{DL}$ & $<\mathrm{DL}$ & $<\mathrm{DL}$ & 383 & 300 & 33 & 115 & 158 \\
\hline & August & $<\mathrm{DL}$ & 77 & $<\mathrm{DL}$ & $<\mathrm{DL}$ & $<\mathrm{DL}$ & $<\mathrm{DL}$ & $<\mathrm{DL}$ & $<\mathrm{DL}$ & 75 \\
\hline \multirow[t]{3}{*}{ Effluent } & April & $<\mathrm{DL}$ & $<\mathrm{DL}$ & $<\mathrm{DL}$ & 78 & 747 & 54 & 36 & 181 & $<\mathrm{DL}$ \\
\hline & May & 4600 & $<\mathrm{DL}$ & $<\mathrm{DL}$ & $<\mathrm{DL}$ & 201 & 342 & 37 & 192 & 65 \\
\hline & August & $<\mathrm{DL}$ & $<\mathrm{DL}$ & $<\mathrm{DL}$ & 99 & 195 & $<\mathrm{DL}$ & $<\mathrm{DL}$ & $<\mathrm{DL}$ & 68 \\
\hline \multirow[t]{3}{*}{ Down-stream } & April & $<\mathrm{DL}$ & $<\mathrm{DL}$ & $<\mathrm{DL}$ & $<\mathrm{DL}$ & 593 & $<\mathrm{DL}$ & 5 & 6 & $<\mathrm{DL}$ \\
\hline & May & 741 & $<\mathrm{DL}$ & $<\mathrm{DL}$ & $<\mathrm{DL}$ & $<\mathrm{DL}$ & $<\mathrm{DL}$ & $<\mathrm{DL}$ & $<\mathrm{DL}$ & $<\mathrm{DL}$ \\
\hline & August & 739 & $<\mathrm{DL}$ & $<\mathrm{DL}$ & $<\mathrm{DL}$ & $<\mathrm{DL}$ & 82 & $<\mathrm{DL}$ & $<\mathrm{DL}$ & $<\mathrm{DL}$ \\
\hline \multirow[t]{3}{*}{ Upstream 1} & April & $<\mathrm{DL}$ & $<\mathrm{DL}$ & $<\mathrm{DL}$ & 29 & 581 & $<\mathrm{DL}$ & 3 & 1 & $<\mathrm{DL}$ \\
\hline & May & 674 & $<\mathrm{DL}$ & $<\mathrm{DL}$ & $<\mathrm{DL}$ & 91 & 84 & $<\mathrm{DL}$ & $<\mathrm{DL}$ & $<\mathrm{DL}$ \\
\hline & August & 634 & $<\mathrm{DL}$ & $<\mathrm{DL}$ & $<\mathrm{DL}$ & 259 & 42 & $<\mathrm{DL}$ & $<\mathrm{DL}$ & 56 \\
\hline \multirow[t]{2}{*}{ Upstream 2} & April & $<\mathrm{DL}$ & $<\mathrm{DL}$ & 535 & 173 & 969 & $<\mathrm{DL}$ & 4 & 7 & $<\mathrm{DL}$ \\
\hline & May & 743 & $<\mathrm{DL}$ & $<\mathrm{DL}$ & $<\mathrm{DL}$ & $<\mathrm{DL}$ & 113 & $<\mathrm{DL}$ & $<\mathrm{DL}$ & $<\mathrm{DL}$ \\
\hline \multirow{2}{*}{ Upstream 3} & May & 903 & $<\mathrm{DL}$ & $<\mathrm{DL}$ & $<\mathrm{DL}$ & $<\mathrm{DL}$ & 105 & $<\mathrm{DL}$ & $<\mathrm{DL}$ & $<\mathrm{DL}$ \\
\hline & August & 597 & $<\mathrm{DL}$ & $<\mathrm{DL}$ & $<\mathrm{DL}$ & $<\mathrm{DL}$ & $<\mathrm{DL}$ & $<\mathrm{DL}$ & $<\mathrm{DL}$ & $<\mathrm{DL}$ \\
\hline \multirow[t]{3}{*}{ Upstream 4} & April & $<\mathrm{DL}$ & $<\mathrm{DL}$ & $<\mathrm{DL}$ & $<\mathrm{DL}$ & 600 & $<\mathrm{DL}$ & 4 & 1 & $<\mathrm{DL}$ \\
\hline & May & 798 & $<\mathrm{DL}$ & $<\mathrm{DL}$ & $<\mathrm{DL}$ & $<\mathrm{DL}$ & 118 & $<\mathrm{DL}$ & $<\mathrm{DL}$ & $<\mathrm{DL}$ \\
\hline & August & 622 & $<\mathrm{DL}$ & $<\mathrm{DL}$ & $<\mathrm{DL}$ & $<\mathrm{DL}$ & $<\mathrm{DL}$ & $<\mathrm{DL}$ & $<\mathrm{DL}$ & $<\mathrm{DL}$ \\
\hline \multirow[t]{3}{*}{ Upstream 5} & April & $<\mathrm{DL}$ & $<\mathrm{DL}$ & $<\mathrm{DL}$ & $<\mathrm{DL}$ & 560 & $<\mathrm{DL}$ & 4 & 1 & $<\mathrm{DL}$ \\
\hline & May & 772 & $<\mathrm{DL}$ & $<\mathrm{DL}$ & $<\mathrm{DL}$ & $<\mathrm{DL}$ & 97 & $<\mathrm{DL}$ & $<\mathrm{DL}$ & $<\mathrm{DL}$ \\
\hline & August & 1032 & $<\mathrm{DL}$ & $<\mathrm{DL}$ & $<\mathrm{DL}$ & $<\mathrm{DL}$ & $<\mathrm{DL}$ & $<\mathrm{DL}$ & $<\mathrm{DL}$ & $<\mathrm{DL}$ \\
\hline \multirow[t]{3}{*}{ Upstream 6} & April & $<\mathrm{DL}$ & $<\mathrm{DL}$ & 844 & 33 & 606 & $<\mathrm{DL}$ & 5 & 1 & $<\mathrm{DL}$ \\
\hline & May & 410 & $<\mathrm{DL}$ & $<\mathrm{DL}$ & $<\mathrm{DL}$ & 120 & 120 & $<\mathrm{DL}$ & $<\mathrm{DL}$ & 55 \\
\hline & August & 639 & $<\mathrm{DL}$ & $<\mathrm{DL}$ & $<\mathrm{DL}$ & $<\mathrm{DL}$ & $<\mathrm{DL}$ & $<\mathrm{DL}$ & $<\mathrm{DL}$ & $<\mathrm{DL}$ \\
\hline \multirow[t]{3}{*}{ Upstream 7} & April & $<\mathrm{DL}$ & $<\mathrm{DL}$ & 211 & 67 & 734 & $<\mathrm{DL}$ & 4 & 1 & $<\mathrm{DL}$ \\
\hline & May & 696 & $<\mathrm{DL}$ & $<\mathrm{DL}$ & $<\mathrm{DL}$ & $<\mathrm{DL}$ & 90 & $<\mathrm{DL}$ & $<\mathrm{DL}$ & 58 \\
\hline & August & 766 & $<\mathrm{DL}$ & $<\mathrm{DL}$ & $<\mathrm{DL}$ & $<\mathrm{DL}$ & $<\mathrm{DL}$ & $<\mathrm{DL}$ & $<\mathrm{DL}$ & $<\mathrm{DL}$ \\
\hline
\end{tabular}

